\title{
Solid Particle Emission Abatement from Biomass-Fired Boilers at District Heating Plants
}

\author{
Egils Dzelzitis ${ }^{1}$, Aldis Jegeris ${ }^{2}$, Agnese Lickrastina ${ }^{1}$ and Normunds Talcis ${ }^{2}$ \\ 1. Heat, Gas and Water Technology Institute, Riga Technical University, Riga, LV-1048, Latvia \\ 2. District Heating Company "Rigas Siltums", Riga, LV-1012, Latvia
}

Received: August 04, 2015 / Accepted: February 15, 2016 / Published: March 31, 2016.

\begin{abstract}
The district heating company "Rigas siltums" operates biomass fuelled boiler in Riga city. Three systems consisting of biomass boilers having a comparatively similar heat capacity and particle abatement units like multicyclons, electrostatic precipitators and flue gas condensers are compared. The main goal of the study is to evaluate the boiler plant as a system where solid particles are both emitted and caught. The results show that, the particulate matter can be efficiently trapped from flue gases by the particle abatement technologies, and the electrostatic precipitator with sufficiently large collection surfaces is able to provide appropriate flue gas treatment of the particulate matter in the biomass boilers also without pre-cleaning of the flue gas in multicyclons.
\end{abstract}

Key words: Biomass, district heating plant, particulate formation, particulate abatement.

\section{Introduction}

The strong environmental requirements and the EU decision to decrease the share of the imported fuels in the Europe's energy balance promote the utilization of the local energy resources in combination with the best practice of the environmental protection technologies [1].

Wood and wood residues compose the greatest share among local renewable fuels in Latvia thus becoming a very attractive and sustainable alternative also in large district heating systems. The main disadvantage of the biomass combustion is ash related problems. For medium to large scale applications, the particulate abatement at the back of the combustion chamber is needed for the further decrease of the particulate matter amount [2]. In order to reach the particle emission requirements, the heat production unit should be considered as a system where all parts are influencing each other and each of them is important.

Corresponding author: Agnese Lickrastina, Dr.sc.ing, docent, research fields: district heating, environmental issues and biomass combustion.
Three different types of wood chips boilers located at district heating plants are analyzed in this article. The boiler plants have comparatively similar loads and are connected to the same district heating network. The boilers have different combustion conditions and utilize different particle abatement technologies.

There are usually three different types of biomass ashes considered in the plants-bottom ash, coarse fly ash and fine fly ash. Bottom ash constitutes the major fraction and is characterized by the presence of sand, stones and soil. These fractions decrease the melting point thus causing slag formation. Cyclone ash is finer and consists of inorganic ash particles. This ash fraction is mainly composed of coarse fly ash. The filters, electrostatic precipitators and gas condensation units collect the finest fly ash particles which normally consist of aerosols [3].

According to the Latvian regulations, the permissible emission limit for particulate matter emissions from the boiler plants with the installed heat capacity from $10 \mathrm{MW}$ up to $50 \mathrm{MW}$ fuelled by solid fuels or wood chips must be below $500 \mathrm{mg} / \mathrm{m}^{3}$ with the $6 \%$ oxygen content in the flue gases [4]. 
The chemical properties of biomass vary that, hence, causes variations in chemical composition of biomass ashes. The ash concentration for wood chips varies depending on the wood type and on the presence of bark and inorganic materials like sand and stones. It is known that, wood bark has the highest ash content directly influencing the ash concentration of biomass fuel. The major part of wood ash is typically composed of calcium (Ca) and potassium (K), part of which volatilizes during the combustion and forms fine particles [5]. According to the data in Ref. [6], the mass concentration of fly ash particles behind the boiler is in the range of $60-3,000 \mathrm{mg} / \mathrm{nm}^{3}$.

Wood bark typically has also a comparatively high concentration of heavy metals ( $\mathrm{Zn}$ and $\mathrm{Cd}$ ) which are mostly recovered in fly ash as they vaporize during the combustion. They often are found on the surface of fine fly ash particles or in aerosols [3]. It is found in Ref. [7] that, the fine ash fraction from a woody biomass is typically formed by potassium sulphates, chlorides and carbonates.

The data from Ref. [8] give a general overview about the distribution among biomass ashes (Table 1). It shows that, more than $60 \%$ of the total amount of ash is composed of coarse ash with the particle diameter more than $50 \mu \mathrm{m}$, whereas fine ash constitutes $2 \%-20 \%$. There are large variations for the same type of biomass fuel characterizing the huge diversity of the biomass constituents.

During the complete combustion, all inorganic particles originated from the minerals present in the fuel are divided into two large groups. The large particles form bottom ash and are carried away from the combustion zone by the ash conveyor. The smaller particles called fly ash are taken by flue gases. The latter need particular attention in the operation of the biomass combustion units.

Fly ash is defined as PM (particulate matter) and is characterized by the size of its particles. The fly ash from the combustion of wood is set for the total amount of solid particles, for $\mathrm{PM}_{10}$ and $\mathrm{PM}_{2.5}$. Particular
Table 1 Mass percentage of ash from biomass combustion.

\begin{tabular}{llll}
\hline Particle size $(\mu \mathrm{m})$ & Fuel ash & Bark & Chipping \\
\hline$>50$ & Coarse & $65-85$ & $60-90$ \\
$<10$ & Cyclone ash & $10-25$ & $50-70$ \\
$<1$ & Fine ash & $2-10$ & $10-20$ \\
\hline
\end{tabular}

attention in biomass combustion is paid to the formation of $\mathrm{PM}_{10}$ characterizing particles with the aerodynamic diameter less than $10 \mu \mathrm{m}$. These would include both coarse and fine particles. Attention should be also paid to $\mathrm{PM}_{2.5}$, i.e., to particles with the diameter less than $2.5 \mu \mathrm{m}$ that are removed from the combustion zone by flue gases.

There are several particle abatement technologies most commonly used for flue gases cleaning, such as cyclones, electrostatic precipitators and wet scrubbers which are often used as flue gas condensers [9].

Relatively large particles can be easily trapped by means of multicyclones. Multicyclones are often used for pre-cleaning of the flue gas in front of the flue gas condensation unit [5]. Multicyclones are known as simple-design units with low to moderate gas side pressure drop, inexpensive and working in a wide range of temperatures. The main disadvantages of multicyclones are the low efficiency of small particle collection and the lower total operation efficiency under part-load conditions $[8,10]$. The typical efficiency of cyclones is $55 \%-99 \%$ for particles from $1.0 \mu \mathrm{m}$ to $100 \mu \mathrm{m}$, whereas the highest efficiency $(90 \%)$ is reached for particles larger than $10 \mu \mathrm{m}$.

The ESP (electrostatic precipitator) uses electrostatic charges to remove the particulates from the flue gas flow. The electrostatic precipitator is very efficient for very small particles. The disadvantage is its sensitivity to the varying flow rates and amount of particles, as well as the decreased efficiency during its operation [9]. Larger collective surface areas and lower flue gas flows through the ESP lead to a higher particle removal efficiency as dust particles have more time and surface to collect. The efficiency of large ESP units can reach more than $99 \%$ [2]. Due to that, today, the ESP is one of the most widely used technologies for modern heat and power generation 
plants [11].

Flue gas condensers are often designed as wet scrubbers having double effect on the operation of the biomass boiler plant. They act as a particulate abatement technology ensuring the capturing of fine fly ash particles [12] and recovering the latent heat from the flue gas flow. During the operation, the process water is injected into the flue gas condenser. The surface of small droplets absorbs the fine fly ash particles and even the gases from the flue gas flow simultaneously absorbing also the heat from the gas flow. The total surface area of all the droplets is large enough to ensure the high efficiency of the absorption process. The higher is the moisture content in the fuel, the larger amount of heat is carried by the flue gases [8]. Recovering the latent heat significantly increases the boiler efficiency up to $30 \%$. The wood biomass moisture could reach even $55 \%-60 \%$ of the moisture content thus making the flue gas condensers an attractive option for the flue gas treatment in the biomass boiler plants [13].

The measurements at three biomass fuelled boiler plants were made only during the full load operation in order to avoid the influence of the part-load conditions and incomplete burning of the biomass. This ensures that, the particle formation mainly originates from the minerals initially present in the biomass. The boiler plants have different combustion technologies. It is assumed that, the combustion technology has an effect on the amount of solid particles originating during the biomass combustion.

As all boiler plants are fuelled with wood chips delivered by the same biomass fuel production company, significant variations due to the variations in wood chips fuel composition are not expected. Measurements are made behind the boiler and behind each of the flue gas cleaning units, i.e., behind the multicyclone, behind the electrostatic precipitator and behind the flue gas condensing unit. Measurements were made during the last heating season by the licensed companies and only under the actual operating conditions. The obtained results are evaluated in this study. Particular attention was paid to the efficiency of the particulate abatement units installed in the boiler plants. The main goal of the study is to evaluate the boiler plant as a system where solid particles are both emitted and caught. Three systems including biomass boilers and particle abatement units like multicyclons, electrostatic precipitators and flue gas condensers are compared in this study.

\section{Evaluation of the Efficiency of Particulate Abatement Technologies at the District Heating Plants in Riga}

The district heating company "Rigas siltums" has gradually enlarged the existing boiler plants with the wood chips boilers. Thus the biomass has become the main heat source providing particular care of the flue gas treatment issues. From the environmental protection point of view, the main difference between the formation of gaseous emissions from the natural gas combustion and the biomass combustion is determined by the formation of fly ash in the flue gas. The special regulations by the Latvian environmental protection authority set forth the maximum permissible calculated limits for solid particle emissions for each boiler [14-16].

The particle formation should be initially considered from the combustion process point of view as the ash formation is directly influenced by fuel properties, combustion conditions, appliances, excess air and boiler load [1].

In order to avoid the influence of the incomplete combustion on the ash formation, the full load operation with the optimal air supply is ensured (Table 2). The variations of the fuel composition could be considered insignificant as one and the same biomass fuel production company simultaneously supplies fuel to the three investigated boiler plants. With the complete and efficient combustion provided, 
Table 2 Fixed parameters of the study.

\begin{tabular}{ll}
\hline Fuel & Wood chips delivered by the same company \\
\hline Boiler load & $\begin{array}{l}\text { Full load } \\
\text { Optimal conditions according to the }\end{array}$ \\
Combustion & $\begin{array}{l}\text { Ophnology } \\
\text { techol }\end{array}$ \\
\hline
\end{tabular}

Table 3 Variable parameters of the study.

\begin{tabular}{|c|c|c|c|}
\hline & $\begin{array}{l}\text { District } \\
\text { heating plant } \\
\text { Vecmilgravis }\end{array}$ & $\begin{array}{l}\text { District } \\
\text { heating plant } \\
\text { Zasulauks }\end{array}$ & $\begin{array}{l}\text { District } \\
\text { heating plant } \\
\text { Ziepniekkalns }\end{array}$ \\
\hline $\begin{array}{l}\text { Installed } \\
\text { heating } \\
\text { capacity }\end{array}$ & $14 \mathrm{MW}$ & $20 \mathrm{MW}$ & $22 \mathrm{MW}$ \\
\hline $\begin{array}{l}\text { Combustion } \\
\text { technology }\end{array}$ & $\begin{array}{l}\text { Moving grate } \\
\text { pre-furnace }\end{array}$ & $\begin{array}{l}\text { Bubbling } \\
\text { fluidized-bed } \\
\text { furnace }\end{array}$ & $\begin{array}{l}\text { Rotating } \\
\text { water-cooled } \\
\text { grates }\end{array}$ \\
\hline $\begin{array}{l}\text { Installed } \\
\text { particulate } \\
\text { abatement } \\
\text { technologies }\end{array}$ & $\begin{array}{l}\text { Multicyclones } \\
\text { Flue gas } \\
\text { condenser }\end{array}$ & $\begin{array}{l}\text { Electrostatic } \\
\text { precipitator } \\
\text { Flue gas } \\
\text { condenser }\end{array}$ & $\begin{array}{l}\text { Multicyclone } \\
\text { Electrostatic } \\
\text { precipitator } \\
\text { Flue gas } \\
\text { condenser }\end{array}$ \\
\hline
\end{tabular}

Table 4 Wood chips characteristics.

\begin{tabular}{ll}
\hline Moisture content & $35 \%-40 \%$ \\
Volatiles & $60 \%-80 \%$ \\
Ash content & $2 \%$ \\
\hline
\end{tabular}

the changeable parts are the different combustion technologies and the particulate abatement units installed behind the boiler (Table 3).

The particulate amount in the flue gases is first measured directly behind the boiler. Then the measurements are made repeatedly behind each particulate abatement unit, i.e., behind the multicyclones, the electrostatic precipitators and behind the flue gas condensers. The last measurement behind the flue gas condensers shows the amount of particulate matter blown into the atmosphere.

The efficiency of the flue gas condensers is influenced by the flue gas water content originated from the wood biomass humidity. The moisture content of wood chips could vary from $25 \%$ to $60 \%$. During the study, it was in the range from $35 \%$ to $40 \%$ (Table 4). The content of volatiles generally is high for wood chips and could reach $60 \%-80 \%$ depending of the type of wood species composing the fuel. The ash content varies slightly around $2 \%$.

For the industrial application cases discussed in this article, the most typical composition of the wood chips on dry and ash free basis is the following: carbon around $50 \%$, hydrogen around $6 \%$ and oxygen about $44 \%$.

The combustion technology directly influences the biomass gasification and char combustion process. There are two main technologies for the biomass combustion: fixed bed or fluidized bed. During the fixed bed combustion, the primary combustion air is supplied to the fuel from the bottom. It initiates drying and gasification of the biomass with the subsequent combustion of the char. To ensure complete and reliable fuel combustion, the air is typically supplied also as secondary and tertiary air into two or three locations above the fuel bed. The fixed bed combustion is provided at the district heating plants "Vecmilgravis" and "Ziepniekkalns". At the DHP (district heating plant) "Vecmilgravis", the combustion is ensured by the moving grate pre-furnace, whereas the pre-furnace at the DHP "Ziepniekkalns" is designed with rotating water-cooled grates. The fixed bed systems are designed for biomass with the variable moisture content and variable fuel particle size [17].

A bubbling fluidized bed furnace is installed at the DHP "Zasulauks". In this furnace, the biomass is combusted as a suspension of gas, sand, fuel and ashes. Also, in this case, the primary air is supplied through the bottom of the bed. The fluidized bed systems are flexible with regard to the fuel material, moisture content and at the same time they are sensitive to the fuel particle size $[17,18]$.

\subsection{District Heating Plant "Vecmilgravis"}

In 2010, wood-chip fired water heating boilers were installed at the district heating boiler plant "Vecmilgravis". In 2013, they were equipped with a flue gas condenser in order to increase the capacity of the boiler plant and decrease the particulate matter emitted through the stack.

Now there are two hot water boilers AK-7000 with the total installed heating capacity 14 MW (Fig. 1). Both boilers are equipped with the moving grate 


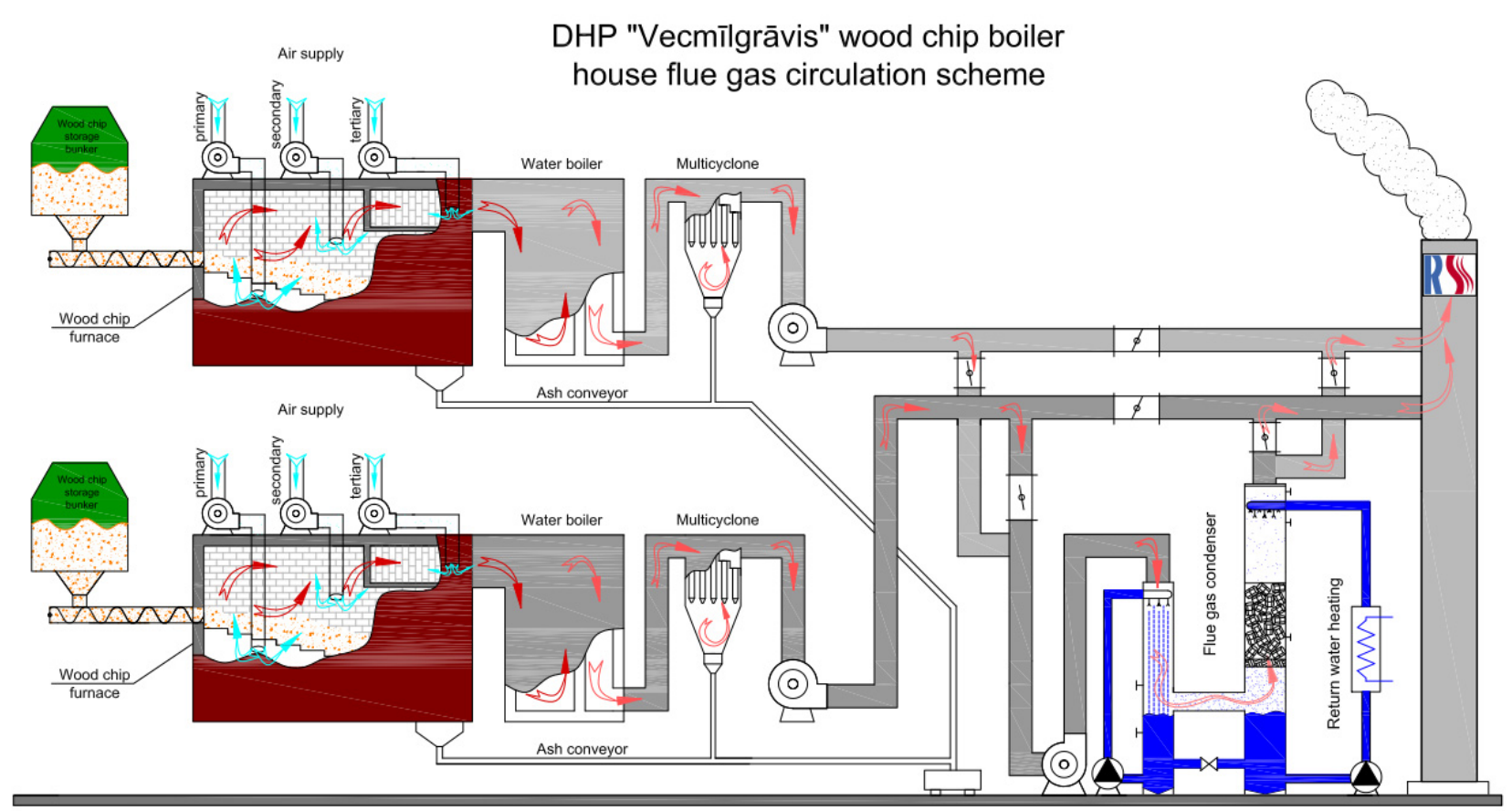

Fig. 1 Flue gas circulation scheme at the DHP "Vecmilgravis".

pre-furnace and hot water boilers with the multicyclones. The multicyclones are of MC-7000 type and they are produced by the local company "Komforts". The total size of each unit is $2,300 \times$ $2,845 \times 4,550 \mathrm{~mm}$ with the DN590 inlet and outlet ports. The capacity of the multicyclon is $7.4 \mathrm{~m}^{3} / \mathrm{s}$. The flue gas condenser is located behind the multicyclone for the further decrease of the particulate emissions.

The measurements were made behind the boiler in order to evaluate the amount of particulates originated during the combustion. The next measuring point was located behind the multicyclone and the third one behind the flue gas condenser. The flow of dry gas through the particulate abatement units reaches 2.05-3.72 Nm/s.

According to the measurements data, the total averaged particulate emissions are $309 \mathrm{mg} / \mathrm{m}^{3}$ directly behind the boilers. The multicyclone entraps more than $70 \%$ of the particles generated during the combustion in the pre-furnace (Fig. 2). The amount of particles behind the multicyclone reduces from $309 \mathrm{mg} / \mathrm{nm}^{3}$ down to $90 \mathrm{mg} / \mathrm{nm}^{3}$.

The particulate matter is further decreased in the flue gas condenser, where about $7 \%$ of the particles initially originated during the combustion are trapped. Due to that, the total amount of particulate matter emitted into the atmosphere consists of $68 \mathrm{mg} / \mathrm{nm}^{3}$, or $22 \%$ of the particles coming out from the boilers (Fig. 2). The maximum permitted amount of particulate emissions leaving the boiler plant could reach $77 \mathrm{mg} / \mathrm{nm}^{3}$ for $\mathrm{PM}_{10}$ and $42 \mathrm{mg} / \mathrm{nm}^{3}$ for $\mathrm{PM}_{2.5}$ [14].

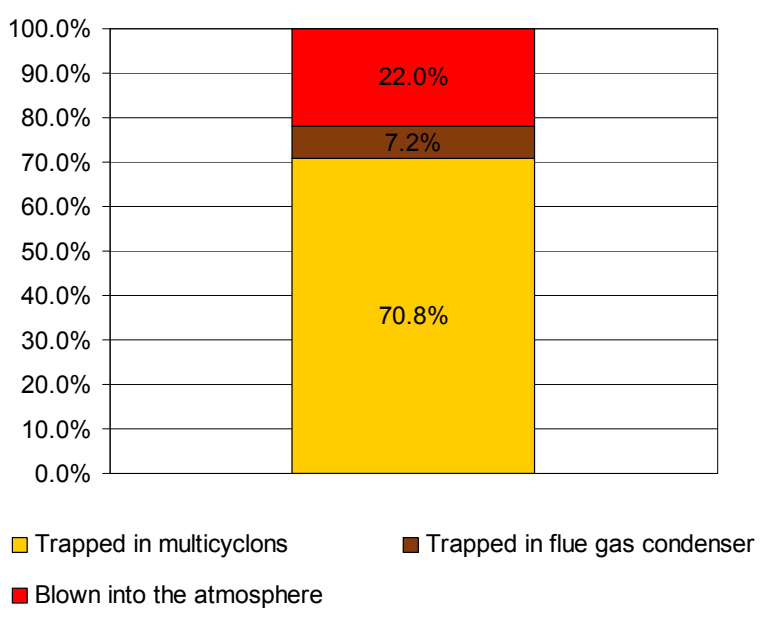

Fig. 2 Trapping distribution of the particulate matter originated in the biomass boilers at the DHP "Vecmilgravis" in the flue gas cleaning devices. 
The comparison between the actual emissions and the maximum allowable emissions shows that, the boiler emits $88 \%$ of the maximum allowable $\mathrm{PM}_{10}$ particulate matter. Assuming that, only coarse fly ash is trapped in the multicyclone, the proportion of fine fly ash from the grate fired boiler is about $30 \%$.

\subsection{District Heating Plant "Zasulauks"}

A water heating boiler with the nominal capacity $20 \mathrm{MW}$ equipped with a bubbling fluidized-bed furnace was installed in 2013 at the district heating plant "Zasulauks".

The water heating boiler is equipped with an electrostatic precipitator and a flue gas condenser (Fig. 3). The electrostatic precipitator has the dimensions $16,064 \times 5,695 \times 18,669 \mathrm{~mm}$ and the dimensions $1,300 \times 1,300 \mathrm{~mm}$ of the inlet and outlet ports. The gas flow through the unit reaches $16 \mathrm{Nm}^{3} / \mathrm{s}$.

The measurements to evaluate the particle abatement from this boiler were made in three places-directly behind the boiler, at the exit of the electrostatic precipitator and between the flue gas condenser and the stack.

The measurements made behind the convective part of the boiler show that, the amount of particles originated during the combustion in the fluidized bed reaches $297 \mathrm{mg} / \mathrm{nm}^{3}$. After leaving the boiler, the flue gases enter the electrostatic precipitator, where the particulate matter amount was decreased by $85 \%$, from $297 \mathrm{mg} / \mathrm{nm}^{3}$ to $42 \mathrm{mg} / \mathrm{nm}^{3}$ (Fig. 4).

After leaving the electrostatic precipitator, the flue gases enter the flue gas condenser primarily designed to improve the boiler plant efficiency. Only a small amount of about $3.3 \%$ of the initially originated amount of particles is trapped there. The final amount of particles leaving the boiler plant is $32.4 \mathrm{mg} / \mathrm{nm}^{3}$, or $10.9 \%$ (Fig. 4). The dry gas flow during the measurements varied from $6.3 \mathrm{Nm}^{3} / \mathrm{s}$ to $9.81 \mathrm{Nm}^{3} / \mathrm{s}$.

The maximum limit for the solid particle emission from the district heating plants "Zasulauks" has been calculated as $84 \mathrm{mg} / \mathrm{m}^{3}$. The maximum permissible amount for the particulate emissions $\mathrm{PM}_{10}$ is set to $29 \mathrm{mg} / \mathrm{nm}^{3}$, whereas the maximum for $\mathrm{PM}_{2.5}$ is $18 \mathrm{mg} / \mathrm{nm}^{3}$ [15].

In fact, the total amount of particulates leaving the boiler plant is less than $40 \%$ of the maximum permissible particulate matter emissions.

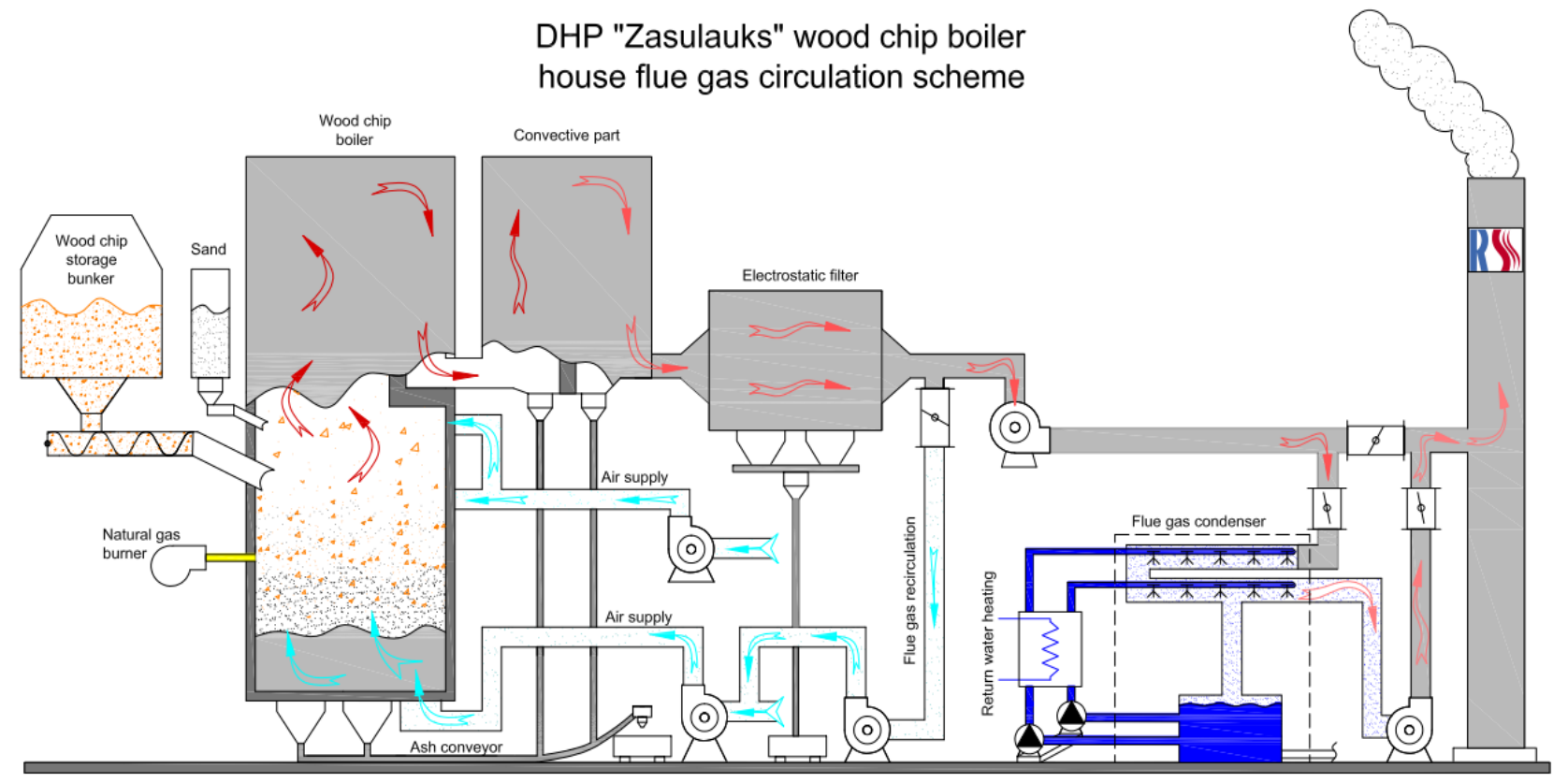

Fig. 3 Flue gas circulation scheme at the DHP "Zasulauks". 


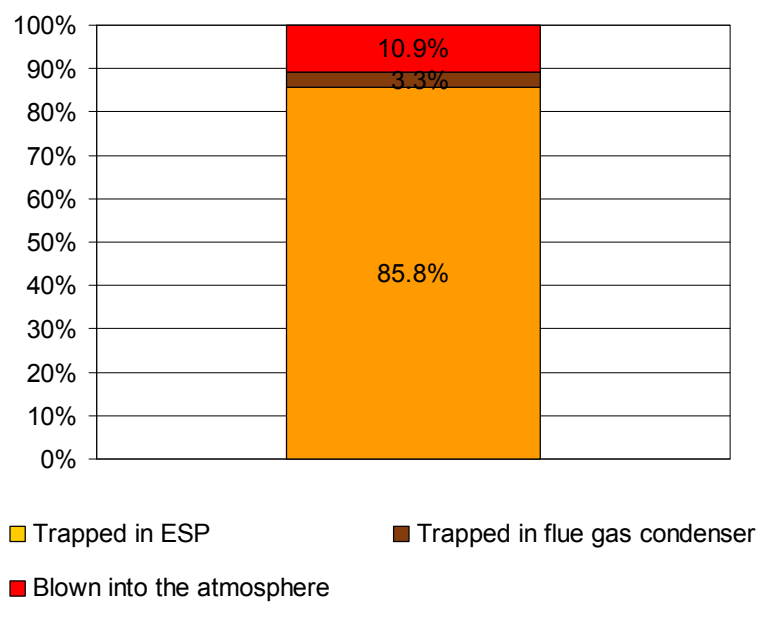

Fig. 4 Trapping distribution of the particulate matter originated in the biomass boilers at the DHP "Zasulauks" in the flue gas cleaning devices.

\subsection{District Heating Plant "Ziepniekkalns"}

The biomass cogeneration steam boiler plant with the installed heat capacity up to $22 \mathrm{MW}$ and electrical capacity $4 \mathrm{MW}$ is in operation since 2013. The pre-furnace for biomass combustion is designed with rotating water-cooled grates. Tangentially supplied secondary and tertiary air provides a stable and complete combustion process. The boiler is equipped with two economizers to ensure the higher total boiler plant efficiency by preheating the water and air supplied for combustion.

After passing the economizers, the flue gases enter the gas cleaning system involving several steps. Firstly, the gases pass through the multicyclone and then through the electrostatic precipitator. The flue gas condenser is installed between the electrostatic precipitator and the stack (Fig. 5). The multicyclone wellon has been added as a component at the boiler supply. The dimensions of the unit are 2,090 $\times 2,446$ $\times 4,040 \mathrm{~mm}$. The capacity of the multicyclone reaches $13.61 \mathrm{~m}^{3} / \mathrm{s}$ for the flue gases with the temperature below $320{ }^{\circ} \mathrm{C}$, or $6.73 \mathrm{Nm}^{3} / \mathrm{s}$. The gas flow velocity through the multicyclone ranges 4.2-4.5 m/s. The dimensions of the electrostatic precipitator are $10,680 \times 6,700 \times 14,815 \mathrm{~mm}$, with the cross-section area of $3,500 \times 6,000 \mathrm{~mm}$ for the inlet and outlet ports. The consumption of the flue gases is $25.28 \mathrm{~m}^{3} / \mathrm{s}$ at the gas temperature $163{ }^{\circ} \mathrm{C}$, correspondingly, $16.99 \mathrm{Nm}^{3} / \mathrm{s}$.

The measurements were made at the exit of the boiler, behind the multicyclone, behind the electrostatic precipitator and between the flue gas condenser and the stack.

\section{DHP "Ziepniekkalns" wood chip boiler house flue gas circulation scheme}

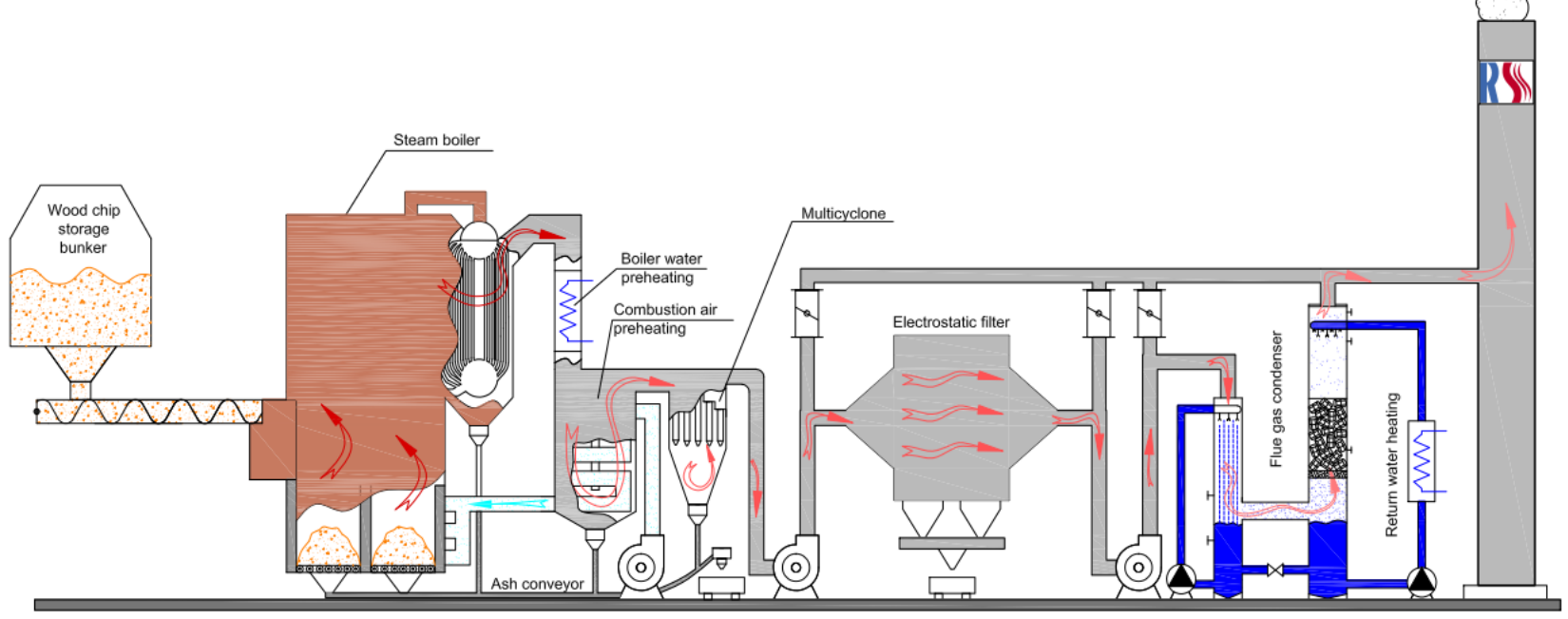

Fig. 5 Flue gas circulation scheme at DHP “Ziepniekkalns". 


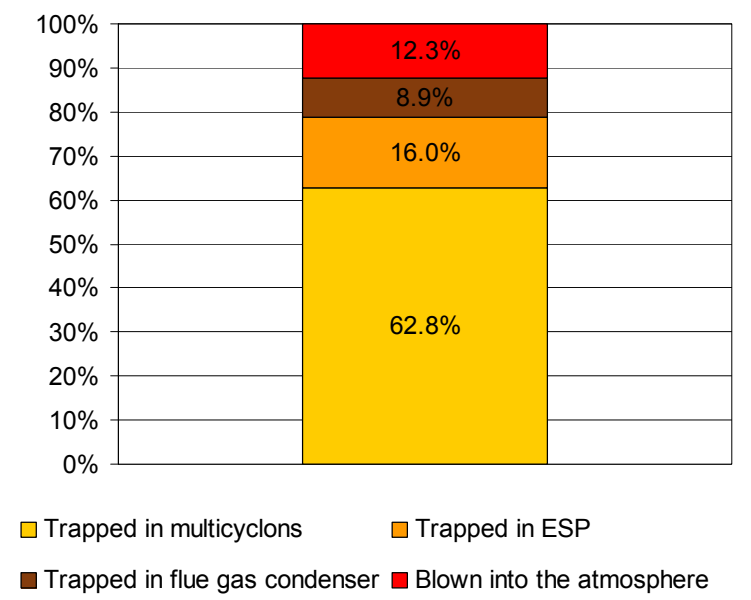

Fig. 6 Trapping distribution of the particulate matter originated in the biomass boilers at the DHP "Ziepniekkalns" in the flue gas cleaning devices.

The total amount of particles originated from the fuel in the combustion zone was $293 \mathrm{mg} / \mathrm{m}^{3}$. The amount of particulate matter was gradually decreasing when passing through the flue gas treatment devices. After leaving the boiler, the coarse dust particles were separated from the flue gas in the multicyclone. About $184 \mathrm{mg} / \mathrm{nm}^{3}$, or $63 \%$ of the particulate matter originated during the combustion were trapped there. Then flue gases entered the electrostatic precipitator, where the amount of particulate matter was decreased to $62 \mathrm{mg} / \mathrm{nm}^{3}$. Upon cleaning, the flue gases were condensed in the flue gas condenser, where about $26 \mathrm{mg} / \mathrm{nm}^{3}$ of the solid particles were trapped. The dry gas flow during the measurements varied from $7.3-7.6 \mathrm{Nm}^{3} / \mathrm{s}$.

As a result, the total amount of particulate matter emitted into the atmosphere is $36 \mathrm{mg} / \mathrm{nm}^{3}$, or only $12 \%$ of the emissions initially originated from the biomass combustion (Fig. 6). For the biomass boiler located at the district heating plant "Ziepniekkalns", the limit for the total amount of particulates is set to $83 \mathrm{mg} / \mathrm{nm}^{3}$. The limits for $\mathrm{PM}_{10}$ and $\mathrm{PM}_{2.5}$ are set to $58 \mathrm{mg} / \mathrm{nm}^{3}$ and $42 \mathrm{mg} / \mathrm{nm}^{3}$, respectively [13]. The particles emitted into the atmosphere constitute only $43 \%$ of the limits set by the environmental protection authority.

\section{Conclusions}

Three systems with different wood chips combustion technologies and slightly different particulate abatement units have been evaluated in this study. Considering the biomass plants as a system consisting of separate units allows selecting an optimal combination under the given circumstances.

During the investigation, the influence of variations of the biomass and combustion conditions has been eliminated. The same biomass producer supplied wood chips simultaneously to all three plants. The optimal combustion conditions according to the combustion technology have been provided in all biomass pre-furnaces. The amounts of fly ash particles from the different types of biomass boilers operated at the district heating company "Rigas siltums" were measured under full load and stable operation during the heating season. The measurements were made behind the boiler and behind each of the flue gas treatment unit.

The measurement data show the comparatively similar solid particle amount originated during the combustion independently on the furnace design. It allows us to conclude that, the combustion technology is not a determining factor for the solid particle formation if the optimal combustion conditions are provided in the furnace and if there are no significant variations of the wood biomass composition (Table 5).

The particulate matter can be efficiently trapped from the flue gases by the particle abatement technologies. The flue gas condensers are an optimal solution for the biomass boiler plants which ensures the recovering of latent heat and the increase of the efficiency with the simultaneous decrease of particulates in the flue gas.

The comparison between multicyclons and electrostatic precipitators has revealed that, the latter could be a good solution for the biomass plants. The results show that, the electrostatic precipitator with sufficiently large collection surfaces is also able to 
Table 5 Particulate emissions from the district heating plants $\left(\mathrm{mg} / \mathrm{m}^{3}\right)$.

\begin{tabular}{llll}
\hline & DHP Vecmilgravis & DHP Zasulauks & DHP Ziepniekkalns \\
\hline Behind the boiler & 309 & 297 & 293 \\
Behind the multicyclons & 90 & - & 184 \\
Behind the ESP & - & 42 & 62 \\
Behind the flue gas condensers/blown into the atmosphere & 68 & 32.4 & 36 \\
Percentage captured by particulate abatement units & $78 \%$ & $89 \%$ & $88 \%$ \\
\hline
\end{tabular}

provide an appropriate flue gas treatment of particulate matter in the biomass boilers avoiding the flue gas pre-cleaning in the multicyclons.

The actual emissions during the measurements constitute about $40 \%$ of the limits set forth by the environmental protection authority and about $9 \%$ of the limits stated by the laws of the Republic of Latvia [4]. This allows to conclude that, the selection of an appropriate particle abatement technology for the biomass boilers cannot be underestimated, and in order to decrease the particulate matter emitted into the atmosphere from the industrial-scale boiler, the proper flue gas treatment of the particles should be considered and appropriate equipment should be installed.

\section{References}

[1] Obaidullah, M., Bram, S., Verma, V. K., and Ruyck, J. D. 2012. "A Review on Particle Emissions from Small Scale Biomass Combustion." International Journal of Renewable Energy Research 2 (1): 147-59.

[2] Nussbaumer, T. T. 2010. Overview on Technologies for Biomass Combustion and Emission Levels of Particulate Matter. Zürich: FOEN (Swiss Federal Office for the Environment), 1-79.

[3] Biedermann, F., and Obernberger, I. 2005. "Ash-Related Problems during Biomass Combustion and Possibilities for a Sustainable Ash Utilisation." Presented at the International Conference "World Renewable Energy Congress" (WREC), Aberdeen, Scotland.

[4] Regulations of the Cabinet of Ministers Nr. 187. 2013. "The Procedure to Prevent, Restrict and Control the Emission of the Air Polluting Substances from Combustion Units." Cabinet of Ministers Nr. 187.

[5] Sippula, O., Hokkinen, J., Puustinen, H., Yli-Pirila, P., and Jokiniemi, J. 2009. "Particle Emissions from Small Wood-Fired Distrcit Heating Units." Energy \& Fuels 23 (6): 2974-82.

[6] Johansson, L. 2002. "Characterisation of Particle
Emissions from Small-Scale Biomass Combustion." Thesis for a degree of licentiate of engineering, Chalmers Univeristy of Technology.

[7] Sippula, O., Hytonen, K., Tissari, J., Raunemaa, T., and Jokiniemi, J. 2007. "Effect of Wood Fuel on the Emissions from a Top-Feed Stove." Energy \& Fuels 21 (2): 1151-60.

[8] Ebert, F. 2001. "Particle Separation for Biomass Combustion, Aerosols from Biomass Combustion." Presented at the International Seminar Organised on Behalf of IEA (International Energy Agency) Bioenergy Task 32: Biomass Combustion and Cofiring, and the Swiss Federal Office of Energy, Zurich, Switzerland.

[9] AEA Technology Plc. 2010. The Assessment of Flue Gas Particulate Abatement in Wood Burning Boilers. Report for Forestry Commission Scotland.

[10] Brunner, T., Obernberger, I., Jöller, M., Arich, A., and Pölt, P. 2001. "Behavoiur of Ash Forming Compounds in Biomass Furnaces-Measurement and Analyses of Aerosols Formed during Fixed-Bed Biomass Combustion." Presented at the International Seminar Organised on Behalf of IEA Bioenergy Task 32: Biomass Combustion and Cofiring, and the Swiss Federal Office of Energy, Zurich, Switzerland.

[11] Mikael, O., Jorma, J., Jouni, H., Pasi, M., and Jarkko, T. 2006. "Views and Conclusions from the FINE Particles-Technology, Environment and Health Technology Programme." In Combating Particulate Emissions in Energy Generation and Industry, edited by Peter, H. Finland: Tekes.

[12] Strand, M., Pagels, J., Szpila, A., Gudmundsson, A., Swietlicki, E., Bohgrd, M., and Sanati, A. 2002. "Fly Ash Penetration through Electrostatic Precipitator and Flue Gas Condenser in a 6 MW Biomass Fired Boiler." Energy \& Fuels 16 (6): 1499-506.

[13] Neuenschwander, P., Good, J., and Nussbaumer, T. 1998. "Combustion Efficiency in Biomass Furnaces with Flue Gas Condensation.” Presented at the Biomass for Energy and Industry, 10th European Conference and Technology Exhibition, Würzburg, Germany. Accessed August 17, 1998. http://www.etsi.org.

[14] Environmental Office of Riga Region, State 
Environmental Office, Ministry of Environmental Protection and Regional Development of the Republic of Latvia. 2010. "Permission of Category A Polluting Activities Nr. RI 10 IA 0005.” Environmental Office of Riga Region, State Environmental Office, Ministry of Environmental Protection and Regional Development of the Republic of Latvia.

[15] Environmental Office of Riga Region, State Environmental Office, Ministry of Environmental Protection and Regional Development of the Republic of Latvia. 2012. "Permission of Category A Polluting Activities RI12IA0001.” Environmental Office of Riga Region, State Environmental Office, Ministry of Environmental Protection and Regional Development of the Republic of Latvia.
[16] Environmental Office of Riga Region, State Environmental Office, Ministry of Environmental Protection and Regional Development of the Republic of Latvia. 2012. "Permission of Category A Polluting Nr. RI12IA0006." Environmental Office of Riga Region, State Environmental Office, Ministry of Environmental Protection and Regional Development of the Republic of Latvia.

[17] Obernberger, I. 2009. "Reached Developments of Biomass Combustion Technologies and Future Outlook." Presented at the 17th European Biomass Conference and Exhibition, Hamburg, Germany.

[18] Sippula, O. 2010. Fine Particle Formation and Emissions in Biomass Combustion, Academic Dissertation. Kuopio: University of Eastern Finland. 